\title{
Characterization of a New Streptomyces Strain, DS3024, That Causes Potato Common Scab
}

J. J. Hao and Q. X. Meng, Department of Plant Pathology, Michigan State University, East Lansing 48824; J. F. Yin, Department of Plant Pathology, University of Georgia, Tifton 31793; and W. W. Kirk, Department of Plant Pathology, Michigan State University, East Lansing

\begin{abstract}
Hao, J. J., Meng, Q. X., Yin, J. F., and Kirk, W. W. 2009. Characterization of a new Streptomyces strain, DS3024, that causes potato common scab. Plant Dis. 93:1329-1334.

A novel strain of Streptomyces (named DS3024) was isolated from a potato field in Michigan in 2006. The taxonomy of the organism was determined by morphology, biochemistry, and genetic analysis. Analysis of the 16S ribosomal RNA gene sequence indicated that the organism was most similar to an isolate of Streptomyces sp., ME02-6979.3a, which is not pathogenic to potato tubers but is distinct from other known pathogenic Streptomyces spp. Strain DS3024 has genes that encode thaxtomin synthetase $(\operatorname{txt} A B)$, which is required for pathogenicity and virulence, and tomatinase (tomA), which is a common marker for many pathogenic Streptomyces spp. However, the necl gene (associated with virulence in most pathogenic Streptomyces spp.) was not detected. The new strain was capable of growth at $\mathrm{pH} 4.5$, caused necrosis on potato tuber slices, and produced thaxtomin A. In greenhouse experiments, DS3024 caused scab symptoms on potato tubers similar to those caused by Streptomyces scabies on tubers of potato cv. Atlantic, which is scab susceptible. We propose that DS3024 is a new strain of Streptomyces capable of causing common scab on potato tubers. The prevalence of this strain of Streptomyces in potatoproducing areas in the north-central United States has not been determined.
\end{abstract}

Potato common scab (PCS), caused by Streptomyces scabies (Thaxt.) Waksman \& Henrici, is indigenous in all potatogrowing areas in the world $(26,33)$ and is ranked the fourth most important potato disease in the United States (24). Several species of Streptomyces can cause PCS but Streptomyces scabies is considered to be predominant (18). The disease has little impact on total potato yield but spoils the appearance, quality, and marketability of the tubers (13).

At least 13 different Streptomyces spp. have been found to cause PCS on potato worldwide $(1,6,17,24)$. For the past 50 years, studies have mainly focused on $S$. scabies as the prevalent pathogen causing PCS. However, other Streptomyces spp. have been reported to be casual agents of PCS, and each differs from S. scabies in their response to cultural practices (e.g., irrigation management). In the United States, several strains of Streptomyces spp. have been characterized as pathogens in addition to the four officially reported species in the United States: S. scabies, $S$. acidiscabies, $S$. europaeiscabiei, and $S$. stelliscabiei (34). It is likely that more

Corresponding author: J. J. Hao

E-mail:jjhao@msu.edu

Accepted for publication 17 August 2009.

doi:10.1094/PDIS-93-12-1329

(C) 2009 The American Phytopathological Society species capable of causing PCS will be found as detection technologies advance. The number of pathogenic Streptomyces spp. may be increasing due to horizontal gene transfer, genetic mechanisms by which bacterial genes can be transferred from one species to another $(4,26,27)$. Clusters of genes that are associated with pathogenicity are referred to as pathogenicity islands (PAIs). The transfer of a PAI from pathogenic Streptomyces spp. into a nonpathogenic species may result in the emergence of a new pathogen $(26,34)$.

The identification and taxonomy of Streptomyces spp. has been based on morphological and physiological characteristics combined with thaxtomin production and pathogenicity tests in vitro and in vivo (33); however, recently, molecular techniques have become more important. Ability to produce thaxtomin toxin is strongly correlated with the pathogen's pathogenicity. Thaxtomin production can be easily detected with bioassays (23) measured by using liquid chromatography/mass spectrometry (LC/MS) or high-performance liquid chromatography (HPLC) analysis. More importantly, DNA-based methods enable fast and accurate detection of thaxtomin and identification of various Streptomyces spp. Although Streptomyces taxonomy is complex, phylogenetic analysis using 16S ribosomal (r)RNA gene sequencing and DNA-DNA hybridization have also been used successfully for species-level identification $(17,21,27,31)$.
The highly conserved genes responsible for pathogenicity among genetically diverse Streptomyces isolates are ideal molecular markers for determination of pathogenicity. The necl gene, for example, has been used as a genetic marker for potential pathogenicity in breeding programs. This gene encodes a secreted necrogenic protein (14), Nec1, and ectopic expression of necl is sufficient to convert nonpathogenic $S$. lividans into a pathogen $(2,3)$. The necl gene is thought to be highly conserved in both structure and function among unrelated pathogenic Streptomyces spp., and is not known to be present in nonpathogenic species $(2,17,27)$. Pathogenic strains of $S$. scabies, $S$. acidiscabies, and $S$. turgidiscabies may produce both Nec1 and thaxtomin A but necl is not required for thaxtomin A production $(2,3)$. The role of necl is not conclusive. Joshi et al. (14) showed that necl was necessary for pathogenicity but others suspected it to have a subsidiary role in pathogenicity, because it is missing from some other pathogenic strains of Streptomyces $(2,17,33)$.

Studies have shown a correlation between pathogenicity and thaxtomin production $(2,20,24,25)$. Mutant $S$. scabies isolates with reduced or undetectable levels of thaxtomin were nonpathogenic or had reduced virulence (10). The txtA and txt $B$ genes in Streptomyces spp. encode a nonribosomal peptide synthase responsible for synthesis of thaxtomin A toxin. They are arranged in an operon and translationally coupled. This operon can be used as a molecular marker for pathogenicity. Loria et al. (26) reported a strong correlation between thaxtomin production and plant pathogenicity in diverse Streptomyces spp. In addition to thaxtomin and Nec1, no other pathogenicity factors have been found, although some pathogenic isolates may not produce thaxtomin $(27,29,33)$. Hence, the $t x t A B$ and necl genes are presently the best molecular markers for detection of pathogenic Streptomyces spp. using polymerase chain reaction (PCR; 9).

The appearance of new taxa of scabcausing Streptomyces spp. is most likely dependent on horizontal gene transfer, as described above $(4,26,27)$. We isolated genetically and phenotypically distinct Streptomyces spp. as part of a preliminary survey in Michigan (7). Although some isolates were distinct from the known ref- 
erence strains of pathogenic Streptomyces spp., they were closely related to other nonpathogenic species. For example, some were tolerant to $\mathrm{pH} 4.5$ but, according to $16 \mathrm{~S}$ sequence analysis, were not $S$. acidiscabies, which is tolerant to low $\mathrm{pH}$ conditions (18). In addition, some pathogenic Streptomyces isolates that we obtained lacked either necl or tomA genes but were pathogenic on potato tubers. One strain of Streptomyces (named DS3024), which was represented by a single isolate, was distinct both genetically and phenotypically from known pathogenic Streptomyces spp. This strain did not belong to any of the known pathogenic Streptomyces spp. but still caused typical PCS symptoms on potato tubers.

Currently, the statewide distribution of DS3024 in Michigan is unknown. The basic biology and genetics of this pathogen should be addressed before working on large-scale distribution surveys and analyses to enable accurate diagnostics. Our objectives in this study were to characterize the Streptomyces strain DS3024 isolated from soil collected from a potato field in Michigan using morphological, physiological, and molecular methods; determine its taxonomic position; and test its pathogenicity on potato in laboratory and greenhouse conditions. A preliminary report of this study was published (7) and the sequence of DS3024 16S rDNA has been submitted to the National Center for Biotechnology Information GenBank (accession FJ238114).

\section{MATERIALS AND METHODS}

Isolates of Streptomyces spp. Streptomyces strain DS3024 was isolated from soil collected from a potato field in central Michigan. Plants in this field showed symptoms of PCS and the level of disease incidence was high. After harvest on 16 September 2006, a bulk soil sample (2.0 liters total) was collected from 10 sites within the field. Individual samples of about 0.2 liter were collected with an auger to a depth of $15 \mathrm{~cm}$ and placed in a paper bag. The samples were combined in the laboratory by hand-shaking in the bag. Plant debris and stones were manually removed and the remaining soil sample was air dried at $20^{\circ} \mathrm{C}$ for 1 week at $15 \%$ relative humidity. Drying eliminates other microorganisms in the soil that require moisture and potentially compete with Streptomyces spp. because the spores of Streptomyces spp. can survive in dry soil. The soil sample (10 g) was suspended in $90 \mathrm{ml}$ of sterile distilled water and shaken at $200 \mathrm{rpm}$ for $10 \mathrm{~min}$ at $20^{\circ} \mathrm{C}$. The soil solution was serially diluted and spread onto Streptomyces selective medium STR (5). The plates were incubated at $28^{\circ} \mathrm{C}$ for 14 days. Colonies of characteristic Streptomyces spp. were picked and serially transferred until a pure culture was obtained for further analysis. Reference strains of S. scabies (American Type Culture Collection [ATCC] 48173) and $S$. acidiscabies (ATCC 49003) were obtained from the ATCC and Leslie Wanner, United States Department of AgricultureAgricultural Research Service, Beltsville, MD. The isolates were maintained in longterm storage as spore suspensions in $20 \%$ glycerol at $-80^{\circ}$ C. Strain DS3024 and several other isolates, which survived low $\mathrm{pH}$ value on agar media, were selected.

Morphological and physiological characterization. The isolates of Streptomyces were maintained on International Streptomyces Project (ISP) Medium 2 (yeast malt extract [YME]). Morphology of spore chains, color, and ornamentation of spores were assessed as described by Shirling and Gottlieb (30) and examined by scanning electron microscopy. The sample used for scanning electron microscopy was prepared by the method of Eguchi et al. (8). Characteristics of the spores from 14-day-old cultures on YME at $28^{\circ} \mathrm{C}$ were determined by microscopy. Cultural characteristics of cells in ISP media 2, 6, and 7 were recorded after incubation for 14 days at $28^{\circ} \mathrm{C}$ by the methods recommended by Shirling and Gottlieb (30). Production of dark, diffusible melanoid pigment was determined on peptone-yeast extract iron agar (ISP medium 6) and in tyrosine agar (ISP medium 7). The plates were incubated at $28^{\circ} \mathrm{C}$ and the morphological descriptions of colonies were recorded after 14 days. Cultures of the isolates were grown on STR medium without antibiotics at $\mathrm{pH} 4.0,4.2,4.5,5.0,6.0$, and 7.2 .

Molecular characterization. Extraction of genomic DNA. Streptomyces isolates were grown at $28^{\circ} \mathrm{C}$ for 10 days on YME agar medium. The cells were removed from the plate with a toothpick and resuspended in $500 \mu \mathrm{l}$ of lysis buffer (1.86 $\mathrm{g}$ of $\mathrm{KCl}, 0.605 \mathrm{~g}$ of Tris- $\mathrm{HCl}, 500 \mu \mathrm{l}$ of Tween 20 , and $450 \mathrm{ml}$ of water, adjusted to $\mathrm{pH}$ 8.3; the final volume was brought up to $500 \mathrm{ml}$ with water). The suspension was boiled for $15 \mathrm{~min}$ at $100^{\circ} \mathrm{C}$ and centrifuged for $1 \mathrm{~min}$ at $9,391 \times g$. The supernatant containing genomic DNA was used for the molecular analysis. The amount and purity of the DNA preparations was checked by a NanoDrop ND-1000 (Thermal Scientific, Wilmington, DE).

Sequencing of the 16S rRNA gene. The $16 \mathrm{~S}$ rRNA gene was amplified from DNA of Streptomyces isolates by PCR using the primers $16 \mathrm{~S}-1 \mathrm{~F} \quad\left(5^{\prime}\right.$-CATTCACGGAGA GTTTGATCC- $\left.3^{\prime}\right)$ and 16S-1R (5'AGAAAGGAGGTGATCCAGCC-3') (32). Amplification was carried out in $20 \mu$ of reaction system containing $10 \mathrm{mM}$ Tris$\mathrm{HCl}$ (pH 9.0), $50 \mathrm{mM} \mathrm{KCl}, 0.1 \%$ Triton $\mathrm{X}$ $100,1.0$ to $2.0 \mathrm{mM} \mathrm{MgCl} 2,250 \mu \mathrm{M}$ each dNTP, 10 pmol each primer, Taq DNA polymerase at $5 \mathrm{U} / \mu \mathrm{l}, 2$ to $25 \mathrm{ng}$ DNA template, and MilliQ water to bring the volume to $20 \mu \mathrm{l}$. The thermal cycler was set to the following conditions: initial denaturation at $95^{\circ} \mathrm{C}$ for $3 \mathrm{~min}$; followed by 40 cycles of denaturing at $95^{\circ} \mathrm{C}$ for $20 \mathrm{~s}$, annealing at $60^{\circ} \mathrm{C}$ for $30 \mathrm{~s}$, and extension at $72^{\circ} \mathrm{C}$ for $2 \mathrm{~min}$; and ending with a $4^{\circ} \mathrm{C}$ hold. The PCR product of $1,500 \mathrm{bp}$ was verified by agarose gel electrophoresis and purified by using the QIAquick PCR product purification kit (Qiagen Science, MD). The PCR product was sequenced at Michigan State University Genomic Technology Support Facility (East Lansing, MI). The 16S rRNA gene sequences were aligned with the MEGALIGN program of DNASTAR (DNASTAR Inc., Madison, WI). A phylogenetic tree (an unrooted tree and all branch lengths) was constructed using ClustalX version $2(19,28)$, which was based on the neighbor-joining (NJ) method (28). To generate the tree, sequences of $16 \mathrm{~S}$ rDNAs of all the collected isolates were aligned. The distance (percent divergence) was calculated between all pairs of sequences based on the alignment. A distance matrix was generated by the $\mathrm{NJ}$ method. The phylogenetic tree was displayed with the aid of Dendroscope software (12) with 1,000 iterations.

PCR detection of marker genes. Strain DS3024 and other Streptomyces spp. isolates were tested by PCR for the presence of genes characteristic of the S. turgidiscabies PAI as described by Kers et al. (15) using specific primers: TxtAB1 (5'-CCA CCAGGACCTGCTCTTC-3') and TxtAB2 (5'-TCGAGTGGACCTCACAGATG-3') to the $\operatorname{txtAB}$ operon, Tom 3 (5'-GAGGCG TTGGTGGAGTTCTA- $\left.3^{\prime}\right)$ and Tom4 (5'TTGGGGTTGTACTCCTCGTC- $3^{\prime}$ ) to the tomA gene (34), and $\mathrm{Nf}$ (5'-ATGAGC GCGAACGGAAGCCCCGGA-3') and $\mathrm{Nr}$ (5'-GCAGGTCGTCACGAAGGATCG-3') to the necl gene (2). The amplified DNA was separated on a $1.5 \%$ agarose gel to verify the size and presence of the expected 385-bp txtAB, 398-bp tomA, and 700-bp nec1 amplicons. Additional primers for Streptomyces spp. identification based on 16S rDNA were also tested on DS3024. Primers used (34) for Streptomyces spp. included S. scabies and S. europaeiscabiei (scab1m: 5'-CGACACTCT CGGGCATCCGA-3' and scab2m: 5'-TTC GACAGCTCCCTCCCTTAC-3'), S. stelliscabiei (Stel3: 5'-GAAAGCATCAGA GATGGTGCC-3' and T2t2: 5'-CGA CAGCTCCCTCCCCGTAAG- ${ }^{\prime}$ ), $S$. bottropensis (Stel3 and Aci2: 5'-CGA CAGCTCCCTCCCACAAG-3'), S. acidiscabies (Aci1: 5'-TCACTCCTGCCTGCA TGGGCG-3' and Aci2), S. turgidiscabies (Turg1m: 5'-CCCTCGCATGGGGGTGGG TTC-3' and Turg2m: 5'-CGACAGCTC CCTCCCCGTGAG-3'), and $S$. aureofaciens (Aur1: 5'-TCCGCATGGGGGTTG GTG-3' and Aur2: 5'-TGTGAGTCCCCG ACATTACT-3').

Dot blot analysis on nec1 gene. Dot blot analysis was performed to confirm the absence of the necl gene in strain DS3024, 
using strain ATCC 49173 as a control. The necl PCR amplicon (700 bp) was labeled as a probe using PCR digoxigenin (DIG) probe synthesis kit (Roche Applied Science, Mannheim, Germany). Total genomic DNA was extracted and purified using an UltraClean DNA Purification Kit (Mo Bio Laboratories, Inc, Carlsbad, CA). The quantity and quality of the eluted DNA were measured using a NanoDrop. The DNA was diluted in $50 \mu \mathrm{l}$ of $2 \times$ SSC buffer $(1 \times \mathrm{SSC}$ is $0.15 \mathrm{M} \mathrm{NaCl}$ plus 0.015 $\mathrm{M}$ sodium citrate) and denatured by heating at $100^{\circ} \mathrm{C}$ for $5 \mathrm{~min}$, immediately followed by $5 \mathrm{~min}$ of chilling on ice. Two $\mu \mathrm{g}$ of each DNA sample was spotted onto an Amersham Hybond-N+ membrane (GE Healthcare Bio-Sciences Corp., Piscataway, NJ), which was placed on a Whatman $3 \mathrm{MM}$ chromatography paper with a vacuum system underneath. The membrane was baked for $2 \mathrm{~h}$ at $80^{\circ} \mathrm{C}$. Prehybridization $(4 \mathrm{~h})$ and hybridization $(22 \mathrm{~h})$ were carried out using Roche's blotting kits (Roche Applied Science). The blot was placed into a hybridization bag containing prewarmed hybridization buffer and incubated for $30 \mathrm{~min}$ at $65^{\circ} \mathrm{C}$ with gentle agitation. After the incubation, the hybridization buffer was poured out and replaced with new hybridization buffer containing DIG-labeled necl probe, which was prepared by heating the probe in hybridization buffer for $5 \mathrm{~min}$ and chilling on ice for 5 $\min$. The blot was incubated for $20 \mathrm{~h}$ at $65^{\circ} \mathrm{C}$ with gentle agitation. After the hybridization, the membrane was washed for $1 \mathrm{~min}$ in $2 \times \mathrm{SSC} / 1 \%$ sodium dodecyl sulfate (SDS) followed by $60 \mathrm{~min}$ at $68^{\circ} \mathrm{C}$ in $0.1 \times \mathrm{SSC} / 0.1 \%$ SDS for two times. The membrane was then incubated in blocking solution for $30 \mathrm{~min}$ at room temperature, incubated in antibody solution for $30 \mathrm{~min}$, and washed with washing buffer for two times of 15 min each. It was then equilibrated for $5 \mathrm{~min}$ in detection buffer. The CSPD solution (1:100 in detection buffer) was added to the detection buffer and incubated for $5 \mathrm{~min}$. The membrane was dried, autoradiography was performed with Blue Ultra Autorad Film (ISCBioExpress, Kaysville, UT), and film was exposed for 2 min to detect hybridization. This experiment was repeated once.

Pathogenicity assay. Thaxtomin assay. The thaxtomin production of isolate DS3024 was examined and compared with S. scabies ATCC 49173 using HPLC. The assay was conducted following the method described by Loria et al. (23) with slight modifications. Briefly, $200 \mathrm{ml}$ of oatmeal broth with trace elements was inoculated with $200 \mu \mathrm{l}$ of a concentrated spore suspension of Streptomyces strains. The cultures were incubated at $28^{\circ} \mathrm{C}$ at $180 \mathrm{rpm}$ for 7 days. Cultures were centrifuged to remove the cells and particulate materials. The cell pellet was dried and the total weight was measured. Culture super- natants $(15 \mathrm{ml})$ were then extracted twice with an equal volume of ethyl acetate. The combined ethyl acetate extracts were evaporated to dryness and the yellow residue was dissolved in $3 \mathrm{ml}$ of methanol. Thaxtomin A was purchased from Axxora LLC (San Diego, CA) and used as a control standard. Extracts and the thaxtomin A standard were analyzed by LC/MS using a Waters QTof Ultima API mass spectrometer coupled to a Waters 2795 HPLC (Waters, Milford, MA), using electrospray ionization in positive ion mode. A Supelco Ascentis Express C18 column (2.1 by 50 $\mathrm{mm}, 2.7-\mu \mathrm{m}$ particle) was used for separation, using a flow rate of $0.3 \mathrm{ml} / \mathrm{min}$ and a binary linear gradient consisting of solvent $\mathrm{A}=0.1 \%$ aq. formic acid and $\mathrm{B}=$ acetonitrile, programming from $95 \% \mathrm{~A}$ to $10 \% \mathrm{~A}$ from 0 to $7 \mathrm{~min}$ and a hold at 10\%A.

Tuber slice assay. Potato tubers (cv. Atlantic) free from surface diseases were washed and sterilized for 1 min with $10 \%$ bleach $(0.0625 \% \mathrm{NaClO})$. A tissue disk (20 $\mathrm{mm}$ in diameter by $7 \mathrm{~mm}$ in height) was bored from the tuber and placed on moist filter paper in a petri plate (100 by 15 $\mathrm{mm}$ ). Pathogenicity of isolate DS3024 was examined and compared with $S$. scabies ATCC 49173 as described by Loria et al (23). Streptomyces sp. inoculum was prepared from the cultures grown on oatmeal agar medium for 5 to 7 days. Streptomyces spore suspension $(10 \mu \mathrm{l})$ or 3-mm-diameter agar plugs from Streptomyces agar cultures were placed at the center of the potato tuber disks. The disks were incubated in a moist closed container at 22 to $24^{\circ} \mathrm{C}$ in the dark. Necrosis of the tuber slices was evaluated as the final area of necrosis minus the area of inoculation.

Greenhouse experiments. The pathogenicity of the strains was confirmed by greenhouse experiments following the method of Wanner (33) with some modifications. Strain DS3024 and the control strain ATCC 49173 were streaked on fresh YME plates and incubated for 21 days. Bacteria were then washed off using sterile water and the suspensions adjusted to about $10^{6} \mathrm{CFU} / \mathrm{ml}$ using a hemacytometer. Erlenmeyer flasks $(500 \mathrm{ml})$ containing 100 $\mathrm{ml}$ of YME were inoculated with Streptomyces spores $(1 \mathrm{ml})$ in suspension. The culture was incubated in an incubator shaker at $28^{\circ} \mathrm{C}$ for 3 days. The bacterial cells were collected by centrifugation and resuspended in $35 \mathrm{ml}$ of sterile distilled water. The bacterial cell suspension $(5 \mathrm{ml})$ was added to $100 \mathrm{ml}$ of sterile $2 \times$ Say's solution (40 g of sucrose, $2.4 \mathrm{~g}$ of asparagine, $1.2 \mathrm{~g}$ of $\mathrm{K}_{2} \mathrm{HPO}_{4}$, and $20 \mathrm{~g}$ of yeast extract in 1 liter sterile distilled water). Plastic spawn bags (Fungi Perfecti, LLC, Olympia, WA) containing $600 \mathrm{~cm}^{3}$ of vermiculite were sterilized by autoclaving. The vermiculite was inoculated with $5 \mathrm{ml}$ of the bacterial suspension and the bags were then incubated for 14 days at $28^{\circ} \mathrm{C}$ and shaken every second day. The number of Streptomyces sp. spores in the vermiculite was measured at the end of incubation by dilution plating on YME media and colonies of Streptomyces spp. were counted after incubation for 3 days at $28^{\circ} \mathrm{C}$. Plastic pots (volume $=2$ liters) were partially filled with $600 \mathrm{~cm}^{3}$ of a sterilized sand:potting soil $(\mathrm{vol} / \mathrm{vol}=1: 1)$ mixture. Vermiculite inoculum $\left(10^{10} \mathrm{CFU} / 600 \mathrm{~cm}^{3}\right)$ was added to the sterile soil and mixed thoroughly. Certified seed potato tubers of cv. Atlantic, obtained from Dr. D. Douches in the Crop and Soil Sciences Department at Michigan State University, East Lansing, were disinfected by surface sterilization with $15 \%$ bleach $(0.94 \% \mathrm{NaClO})$ for 2 min followed by rinsing in sterile distilled water; seed pieces were then planted at a 15-cm depth. Three replicate plants (pots) were included in each treatment. Plants were watered every 2 to 3 days and fertilizer was applied as needed. Potato plants were grown in the greenhouse for 112 days before harvesting and then scored for disease severity. Scab symptoms were evaluated based the following scale: $0=$ no symptoms, $1=1$ to $10 \%$ surface area with superficial or raised lesions, $2=11$ to $25 \%$ surface area with superficial or raised lesions, $3=26$ to $50 \%$ surface area with superficial or raised lesions, $4=$ more than $50 \%$ surface area with superficial or raised lesions or 6 to $25 \%$ pitted lesion area, and $5=>50 \%$ surface area with superficial or raised lesions or $>25 \%$ pitted area. The experiment was repeated once. Pathogens were isolated from the tuber lesions, purified on STR medium, and genomic DNA of the culture was extracted. PCR was conducted by using primer pair DSF (forward) 5'-TAACACTCTGTTCCGCATGG$3^{\prime}$ and DSR (reverse) 5'-TAGTTCCCA ACGTTTACGGC-3', following the procedures described above. The primers are specific to DS3024. All statistical analysis was conducted using SAS (version 9.1.3; SAS Institute Inc. Cary, NC).

\section{RESULTS}

Morphological and physiological characteristics of the strain DS3024. The morphology of strain DS3024 was consistent with its assignment to the genus Streptomyces. After 14 days of growth, DS3024 produced abundant aerial and vegetative hyphae, which were well developed and exhibited fragmentation. Rough, cylindrical spores were borne in long, flexuous chains (Fig. 1). Growth of aerial and substrate mycelium was found on all media tested. The aerial mycelium of DS3024 varied from white to dark brown in different media (Table 1). The substrate mycelium was colored from yellow to brown. The diffusible pigment melanin was observed on ISP-6 medium. DS3024 can survive at $\mathrm{pH} 4.5$, slightly higher than the minimum of $S$. acidiscabies $(\mathrm{pH} 4.2)$ but much lower than that of S. scabies $(\mathrm{pH}$ 6.0) on STR medium. 
Molecular characterization. The PCR analysis of isolate DS3024 revealed the presence of a homolog of the tomatinase gene, tomA. However, the primer pair amplifying the necl gene yielded no PCR product (Table 2). Seven different sets of PCR primers were used to amplify the $16 \mathrm{~S}$ rDNA sequence characteristic of seven plant-pathogenic Streptomyces spp.: S. scabies, S. europaeiscabiei, S. stelliscabiei, S. bottropensis, S. acidiscabies, S. turgidiscabies, and $S$. aureofaciens. No PCR product was obtained when DS3024 DNA was used as template with those primers, indicating that DS3024 does not belong to any of these species. Dot blot analysis showed that a necl DNA probe hybridized with ATCC49173 genomic DNA but not with DS3024 genomic DNA. This result confirmed that DS3024 lacks a necl homolog.

The complete sequence of the $16 \mathrm{~S}$ rRNA gene from DS3024 was determined (submitted to the GenBank, accession number FJ238114) and it had less than $97 \%$ similarity to the $16 \mathrm{~S}$ rRNA gene from the above Streptomyces spp. but was $99.7 \%$ identical to the $16 \mathrm{~S}$ rRNA sequence of Streptomyces sp. ME02-6979.3a (accession EU080943). Both DS3024 and Streptomyces sp. ME02-6979.3a were clearly separated from the other pathogenic Streptomyces spp. but they were more closely related to $S$. caviscabies and S. luridiscabiei in terms of distance (Fig. 2).

Pathogenicity and thaxtomin production of the strain DS3024. Necrosis was visible $36 \mathrm{~h}$ after inoculation on potato tuber disks inoculated with either DS3024 or ATCC 49173. Necrotic lesions continued to expand over a period of 7 days. No necroses or any color changes of the tuber disks were observed when noninoculated agar was used (Fig. 3A). In greenhouse experiments, scab lesions averaging $5 \mathrm{~mm}$ in depth were observed in potato tubers grown in soil infested with ATCC 49173 and with DS3024 (Fig. 3B). Typical symptoms caused by DS3024 on potato tubers were deep-pitted scabs, with slight variations on the borders of the lesions on the skin, which showed either a clear cut (Fig. $3 \mathrm{~B}$, middle) or a gradual change (Fig. 3B, right) from healthy to diseased tissue. The disease severity of ATCC49173 ranged from 0 to 4 , with an average of $0.7 \pm 1.16$, whereas the disease severity of DS3024 ranged from 0 to 3 with an average of 1.0 \pm 1.11 ; however, there was no significant difference between these two, examined with a $t$ test. The result was consistent in all three experiments. A positive PCR result was shown for strain DS3024 on the reisolated culture from the tuber lesion, indicating that the pathogen that caused scab symptom was DS3024. In HPLC analysis, an abundant ion peak for protonated thaxtomin A was detected in extracts of DS3024 at $\mathrm{m} / \mathrm{z} 439.19$, with a retention time of $4.37 \mathrm{~min}$. Compared with the standard sample, the actual concentration of thaxtomin in the extract solution was calculated as $10.99 \mu \mathrm{g} / \mathrm{ml}$ or $628 \mu \mathrm{g} / \mathrm{g}$ of cells. The extract of ATCC 49173 yielded a barely detectable signal at the same mass and retention time. This indicates that DS3024 produces more thaxtomin than ATCC 49173.

\section{DISCUSSION}

This study demonstrated that DS3024 produced a greater amount of thaxtomin, a required pathogenicity factor in potato scab-causing Streptomyces isolates $(16,23,24)$, than the ATCC 49173 strain. The presence of the thaxtomin synthesis genes was also confirmed by PCR using txtAB primers. Strain DS3024 was aggressive and caused PCS symptoms on potato tubers in the greenhouse. Morphologically, DS3024 did not look like any of the known pathogenic Streptomyces spp. This evidence collectively suggested that DS3024 is a new potato pathogen in the genus Streptomyces.

Table 1. Morphological and physiological characteristics of strain DS3024 grown on different nutrient media

\begin{tabular}{llll}
\hline Medium $^{\mathbf{a}}$ & $\begin{array}{c}\text { Color of } \\
\text { aerial mycelium }\end{array}$ & $\begin{array}{c}\text { Color of } \\
\text { vegetative } \\
\text { mycelium }\end{array}$ & $\begin{array}{c}\text { Production } \\
\text { of soluble } \\
\text { pigment }\end{array}$ \\
\hline Yeast-malt extract agar (ISP medium 2) & Brown & Yellow & Yellow \\
Oatmeal agar (ISP medium 3) & White & White & None \\
Inorganic salts-starch agar (ISP medium 4) & White & White & None \\
Glycerol-asparagine agar (ISP medium 5) & White & White & None \\
Peptone-yeast extract-iron agar (ISP medium 6) & Blackish brown & Brown & Melanin \\
Tyrosine agar (ISP medium 7) & Yellowish white & White & None \\
Czapek's agar & White & White & None \\
Nutrient agar & White & White & None \\
\hline
\end{tabular}

${ }^{\mathrm{a}}$ ISP $=$ International Streptomyces Project.

Table 2. Comparison of strain DS3024 with Streptomyces scabies American Type Culture Collection (ATCC) 49173

\begin{tabular}{lll}
\hline & & Isolate \\
\cline { 2 - 3 } Criteria for comparisons & ATCC 49173 & DS3024 \\
\hline Location & New York & MI \\
Sub mycelium color & Light brown & Reddish brown \\
Spore color & Gray & Light brown \\
Color on yeast malt extract & Orange brown & Whitish yellow \\
Thaxtomin & + & + \\
16S ribosomal RNA similarity & S. scabies & Streptomyces sp. ME02-6979.3 \\
TxtAB gene & + & + \\
TomA gene & + & + \\
necl gene & + & - \\
Pathogenicity & + & + \\
\hline
\end{tabular}
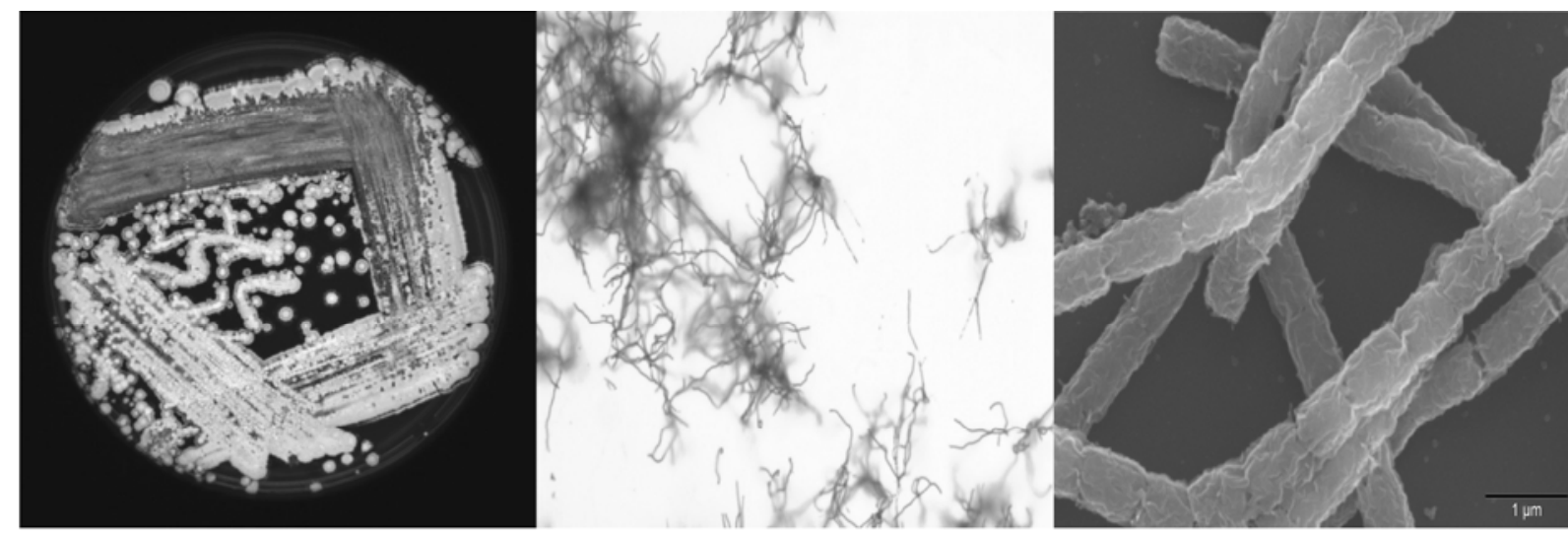

Fig. 1. Morphological properties of Streptomyces strain DS3024. Colonies (left), chain morphology (middle), and ornamentation (right) of spores. 
The necl gene has been reported to be a virulence factor and it has never been found in nonpathogenic strains of Streptomyces. However, in some pathogenic Streptomyces isolates, necl is not required for pathogenicity $(29,33)$. Strain DS3024 has both $t x t A B$ and tomA genes and produces scab lesions on potato tubers despite lacking the necl gene. Similar situations have been reported in Korea (27). Bukhalid et al. (2) reported that, out of 43 tested isolates, a South African S. scabies isolate (CEK 018) produced thaxtomin A but lacked the necl gene (15). Wanner (35) reported a new streptomycete isolated from southeastern Idaho that causes common scab in potato but lacks the necl gene. Isolates of S. scabies from Michigan have been previously reported as having $t x t A B$ but lacking necl and tomA (34). Some of our other isolates of $S$. scabies from the same location as DS3024, which are distinct from DS3024 but have not been tested for pathogenicity, also showed no necl. In a preliminary survey in Michigan soil for Streptomyces spp., some isolates from potato tubers had a variation associated with PAI: some had two but some had all three of the marker genes (txtAB, tomA, and nec1; J. J. Hao, unpublished). This observation supports other reports that Streptomyces spp. can be pathogenic without the necl gene (33).

Although DS3024 is pathogenic on potato tubers, it does not belong to any of the known pathogenic species of Streptomyces. The morphological properties of isolate DS3024 are consistent with its classification within the genus Streptomyces. Strain DS3024 differs in morphology and production of pigmentation in different ISP media (Tables 1 and 2). Some Streptomyces spp., including DS3024, survived lower $\mathrm{pH}$ (as low as 4.2), a condition that was thought to be tolerated only by $S$. acidiscabies.

A phylogenetic tree constructed on the basis of 16S rRNA gene sequence showed that the Streptomyces spp. that cause potato scab, including $S$. acidiscabies, $S$. scabies, and S. turgidiscabies, constitute unique branches. It is evident that strain DS3024 forms a distinct phyletic line from known pathogenic strains and was most closely related to strain ME02-6979.3a, which was described as a potential biological control agent in the GenBank. Strain DS3024 did not look like any of the pathogenic Streptomyces spp. reported earlier. Based on literature and the phylogenetic tree, DS3024 was close to the clade that had $S$. caviscabies (S. griseus), S. setonii, and $S$. argenteolus (22); however, none are known in the United States.

Studies have shown some diversity within strains morphologically identified as $S$. scabies, as well as other phytopathogenic streptomycetes, and provided evidence that potato scab is caused by a polyphyletic group of Streptomyces spp. (11).

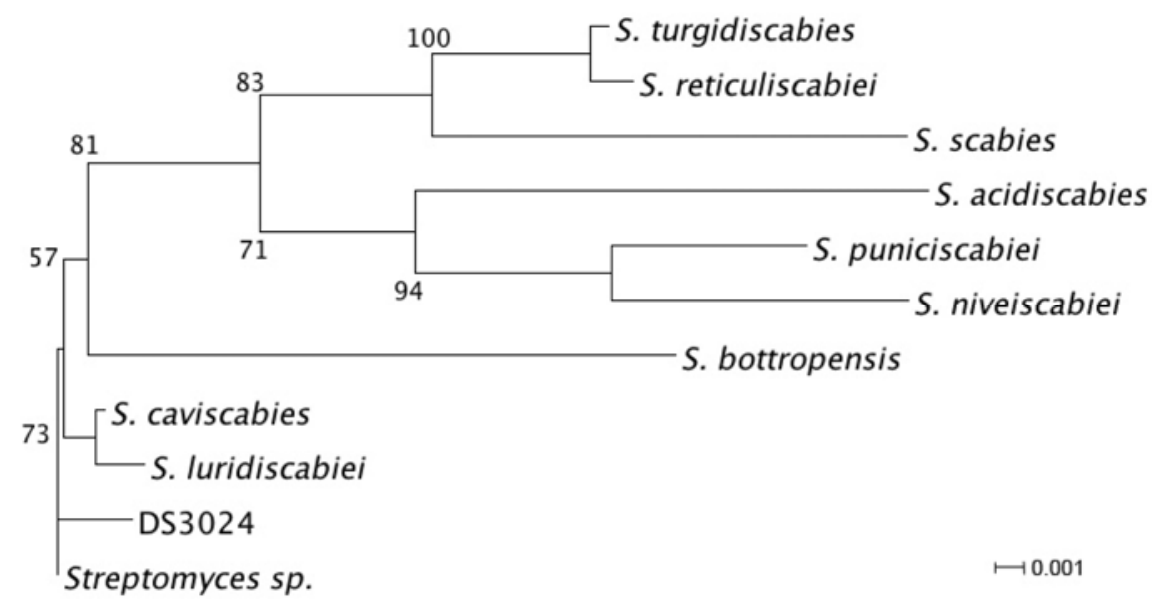

Fig. 2. Phylogenetic tree derived from $16 \mathrm{~S}$ ribosomal (r)RNA gene sequences showing the relationship of strain DS3024 to other Streptomyces spp. The neighbor-joining tree was generated using 16S rDNA sequences. Bootstrap values were obtained with 1,000 replications. The confidence values of tree nodes are shown as percentage of same tree generated. The length of the branches reflects sequence divergence (percentage of base changes). The 16S rDNA sequences of the Streptomyces isolates were downloaded from the GenBank with accession numbers and additional resource information: $S$. acidiscabies (AB026220, American Type Culture Collection [ATCC] 49003), S. bottropensis (AB026217, ATCC 25435), S. caviscabies (AF112160, ATCC 51928), S. europaeiscabiei (AY296988), S. luridiscabiei (AF361784), S. niveiscabiei (AF361786), S. puniciscabiei (AF361785), S. reticuliscabiei (AB0267585), S. scabies (AB026199, ATCC 49173), S. stelliscabiei (AY296989), S. turgidiscabies (AB301484), Streptomyces sp. (EU080943, Wanner's isolate ME02-6979.3a), and DS3024 (FJ238114) from this study.

A

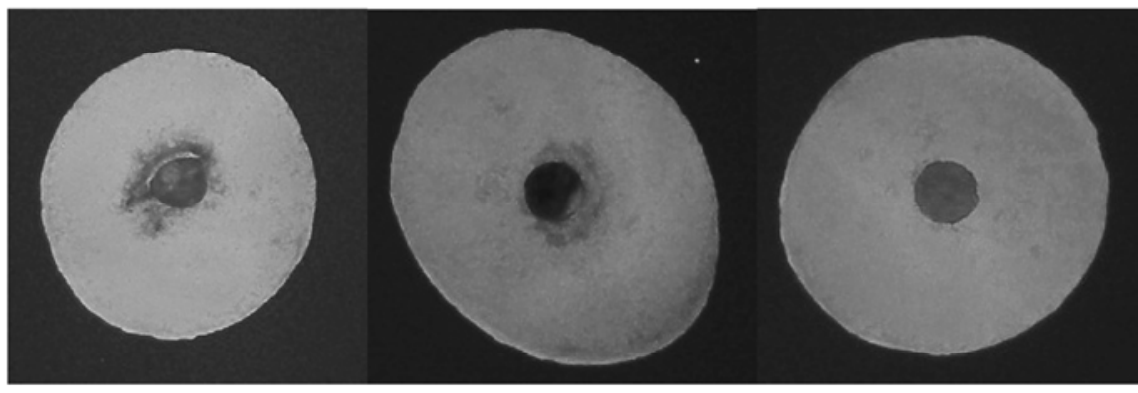

$\begin{array}{lll}\text { ATCC49173 } & \text { DS3024 Agar only }\end{array}$

B

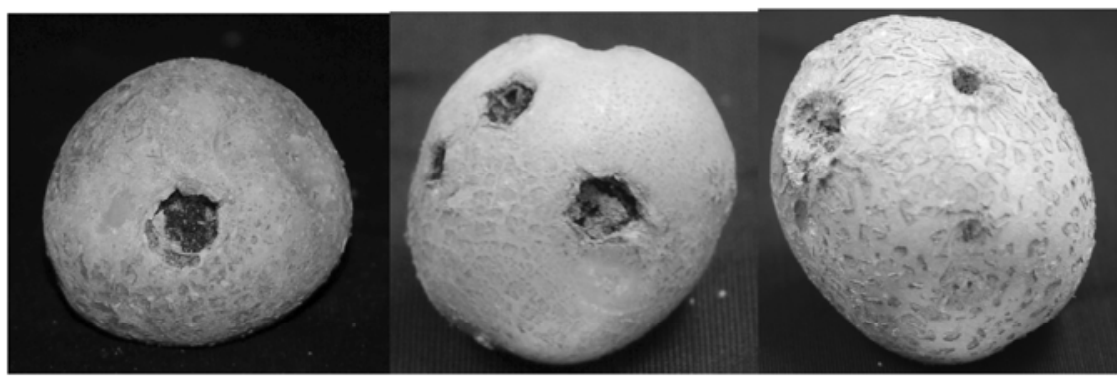

ATCC49173

DS3024

DS3024

Fig. 3. Pathogenicity assay on A, tuber slices of cv. Atlantic: necrotic halos produced around the agar plugs taken from 5-day-old oatmeal agar cultures of Streptomyces scabies American Type Culture Collection [ATCC] 49173 (left), DS3024 (middle), and agar only (right); B, potato tubers showing symptoms of pitted scab caused by S. scabies ATCC 49173 (left) and DS3024 (middle and right) grown in inoculated potting soil in the greenhouse. 
These Streptomyces spp. are different in ecology, host range, virulence, $\mathrm{pH}$ optima, toxin production, and the mechanisms of pathogenicity $(18,27)$. The case of DS3024 could be an example of the occurrence of horizontal gene transfer within these strains (2). It is possible that strain DS3024 was a nonpathogenic soil inhabitant that received a partial PAI cluster (txtAB and tomA) from another pathogenic Streptomyces spp. and then became pathogenic. Genetically, this is very similar to the Idaho strain that Wanner described in terms of PAI genes (35). The absence of a necl homolog in DS3024 indicates that necl is not directly involved in thaxtomin A production and is not a required pathogenicity factor for all streptomycetes. Hence, our study supports the hypothesis that thaxtomin A production is a pathogenicity determinant in plant-pathogenic Streptomyces spp. This finding, along with the apparent lack of necl gene in the isolates from Wanner's (30) study, suggests that North American isolates either contain rearrangements or deletions within the PAI.

In conclusion, isolate DS3024 could be a new pathogenic common scab species in potato. There is need to further investigate whether it is widely distributed. If so, potential risk should be assessed and disease management strategies for this pathogen will require further investigation.

\section{ACKNOWLEDGMENTS}

This project was partially supported by GREEEN fund and Michigan State Agriculture Experiment Station. We thank G. Sundin for critical advice on the research, J. Jacob for technical support, D. Douches for providing potato tubers and some technical help, and L. Triplett for reviewing the manuscript.

\section{LITERATURE CITED}

1. Bouchek-Mechiche, K., Pasco, C., Andrivon, D., and Jouan, B. 2000. Differences in host range, pathogenicity to potato cultivars and response to soil temperature among Streptomyces species causing common and netted scab in France. Plant Pathol. 49:3-10.

2. Bukhalid, R. A., Chung, S. Y., and Loria, R. 1998. necl, a gene conferring a necrogenic phenotype, is conserved in plant-pathogenic Streptomyces spp, and linked to a transposase pseudogene. Mol. Plant-Microbe Interact. 11:960-967.

3. Bukhalid, R. A., and Loria, R. 1997. Cloning and expression of a gene from Streptomyces scabies encoding a putative pathogenicity factor. J. Bacteriol. 179:7776-7783.

4. Bukhalid, R. A., Takeuchi, T., Labeda, D., and Loria, R. 2002. Horizontal transfer of the plant virulence gene, $n e c l$, and flanking sequences among genetically distinct Streptomyces strains in the diastatochromogenes cluster. Appl. Environ. Microbiol. 68:738-744.

5. Conn, K. L., Leci, E., Kritzman, G., and
Lazarovits, G. 1998. A quantitative method for determining soil populations of Streptomyces and differentiating potential potato scabinducing strains. Plant Dis. 82:631-638.

6. Doeringsaad, C., Kampfer, P., Manulis, S., Kritzman, G., Schneider, J., Zakrzewskaczerwinska, J., Schrempf, H., and Barash, I. 1992. Diversity among Streptomyces strains causing potato scab. Appl. Environ. Microbiol. 58:3932-3940.

7. Durairaj, S., Yin, J., Hammerschmidt, R., Kirk, W. W., Douches, D., and Hao, J. 2008. Characterization of a new strain of Streptomycete causing symptoms associated with potato common scab from Michigan soil. (Abstr.) Phytopathology 98:S49.

8. Eguchi, T., Takada, N., Nakamura, S., Tanaka, T., Makino, T., and Oshima, Y. 1993. Streptomyces-Bungoensis sp. Nov. Int. J. Syst. Bacteriol. 43:794-798.

9. Flores-Gonzalez, R., Velasco, I., and Montes, F. 2008. Detection and characterization of Streptomyces causing potato common scab in Western Europe. Plant Pathol. 57:162-169.

10. Goyer, C., Charest, P. M., Toussaint, V., and Beaulieu, C. 2000. Ultrastructural effects of thaxtomin A produced by Streptomyces scabies on mature potato tuber tissues. Can. J. Bot. Rev. Can. Bot. 78:374-380.

11. Healy, F. G., and Lambert, D. H. 1991. Relationships among Streptomyces Spp causing potato scab. Int. J. Syst. Bacteriol. 41:479-482.

12. Huson, D. H., Richter, D. C., Rausch, C., Dezulian, T., Franz, M., and Rupp, R. 2007. Dendroscope: an interactive viewer for large phylogenetic trees. BMC Bioinf. 8:460.

13. Johnson, D. A., and Powelson, M. L. 2008. Potato Health Management. American Phytopathological Society Press, St. Paul, MN.

14. Joshi, M., Rong, X., Moll, S., Kers, J., Franco, C., and Loria, R. 2007. Streptomyces turgidiscabies secretes a novel virulence protein, $\mathrm{Nec} 1$, which facilitates infection. Mol. PlantMicrobe Interact. 20:599-608.

15. Kers, J. A., Cameron, K. D., Joshi, M. V., Bukhalid, R. A., Morello, J. E., Wach, M. J., Gibson, D. M., and Loria, R. 2005. A large, mobile pathogenicity island confers plant pathogenicity on Streptomyces species. Mol. Microbiol. 55:1025-1033.

16. King, R. R., Lawrence, C. H., and Calhoun, L. A. 1992. Chemistry of phytotoxins associated with Streptomyces scabies, the causal organism of potato common scab. J. Agric. Food Chem. 40:834-837.

17. Kreuze, J. F., Suomalainen, S., Paulin, L., and Valkonen, J. P. T. 1999. Phylogenetic analysis of 16S rRNA genes and PCR analysis of the nec1 gene from Streptomyces spp. causing common scab, pitted scab, and netted scab in Finland. Phytopathology 89:462-469.

18. Lambert, D. H., and Loria, R. 1989. Streptomyces scabies sp. nov. nom. Rev. Int. J. Syst. Bacteriol. 39:387-392.

19. Larkin, M. A., Blackshields, G., Brown, N. P., Chenna, R., McGettigan, P. A., McWilliam, H., Valentin, F., Wallace, I. M., Wilm, A., Lopez, R., Thompson, J. D., Gibson, T. J., and Higgins, D. G. 2007. Clustal W and Clustal X version 2.0. Bioinformatics 23:2947-2948.

20. Lawrence, C. H., Clark, M. C., and King, R. R. 1990. Induction of common scab symptoms in aseptically cultured potato tubers by the vivotoxin, thaxtomin. Phytopathology 80:606608.

21. Lehtonen, M. J., Rantala, H., Kreuze, J. F., Bang, H., Kuisma, L., Koski, P., Virtanen, E., Vihlman, K., and Valkonen, J. P. T. 2004 Occurrence and survival of potato scab pathogens (Streptomyces species) on tuber lesions: quick diagnosis based on a PCR-based assay. Plant Pathol. 53:280-287.

22. Liu, Z. H., Shi, Y. L., Zhang, Y. M., Zhou, Z. H., Lu, Z. T., Li, W., Huang, Y., Rodriguez, C., and Goodfellow, M. 2005. Classification of Streptomyces griseus (Krainsky 1914) Waksman and Henrici 1948 and related species and the transfer of 'Microstreptospora cinerea' to the genus Streptomyces as Streptomyces yanii sp. nov. Int. J. Syst. Evol. Microbiol. 55:16051610.

23. Loria, R., Bukhalid, R. A., Creath, R. A., Leiner, R. H., Olivier, M., and Steffens, J. C. 1995. Differential production of thaxtomins by pathogenic Streptomyces species in vitro. Phytopathology 85:537-541.

24. Loria, R., Bukhalid, R. A., Fry, B. A., and King, R. R. 1997. Plant pathogenicity in the genus Streptomyces. Plant Dis. 81:836-846.

25. Loria, R., Coombs, J., Yoshida, M., Kers, J., and Bukhalid, R. 2003. A paucity of bacterial root diseases: Streptomyces succeeds where others fail. Physiol. Mol. Plant Pathol. 62:6572.

26. Loria, R., Kers, J., and Joshi, M. 2006. Evolution of plant pathogenicity in Streptomyces. Annu. Rev. Phytopathol. 44:469 487.

27. Park, D. H., Yu, Y. M., Kim, J. S., Cho, J. M., Hur, J. H., and Lim, C. K. 2003. Characterization of Streptomycetes causing potato common scab in Korea. Plant Dis. 87:12901296.

28. Saitou, N., and Nei, M. 1987. The neighborjoining method-a new method for reconstructing phylogenetic trees. Mol. Biol. Evol. 4:406-425.

29. Seipke, R. F., and Loria, R. 2008. Streptomyces scabies 87-22 possesses a functional tomatinase. J. Bacteriol. 190:7684-7692.

30. Shirling, E. B., and Gottlieb, D. 1966. Methods for characterization of Streptomyces species. Int. J. Syst. Bacteriol 61:352-356

31. Song, J., Lee, S. C., Kang, J. W., Baek, H. J., and Suh, J. W. 2004. Phylogenetic analysis of Streptomyces spp. isolated from potato scab lesions in Korea on the basis of 16S rRNA gene and 16S-23S rDNA internally transcribed spacer sequences. Int. J. Syst. Evol. Microbiol. 54:203-209.

32. Takeuchi, T., Sawada, H., Tanaka, F., and Matsuda, I. 1996. Phylogenetic analysis of Streptomyces spp causing potato scab based on 16S rRNA sequences. Int. J. Syst. Bacteriol. 46:476-479.

33. Wanner, L. A. 2004. Field isolates of Streptomyces differ in pathogenicity and virulence on radish. Plant Dis. 88:785-796.

34. Wanner, L. A. 2006. A survey of genetic variation in Streptomyces isolates causing potato common scab in the United States. Phytopathology 96:1363-1371.

35. Wanner, L. A. 2007. A new strain of Streptomyces causing common scab in potato. Plant Dis. 91:352-359. 